\title{
Enlightenment and virginity
}

\author{
Catherine Addison' \\ Department of English, University of Zululand \\ Caddison@pan.uzulu.ac.za
}

\begin{abstract}
This paper attempts to demystify the vexed question of female virginity using the light of reason and a sceptical, feminist viewpoint. Starting with a historical and cultural survey of beliefs about virginity, it goes on to ask the ontological question What is virginity? In the process of answering this question, it examines biological, historical, psychosexual and cultural evidence to reach the con clusion that virginity does not really exist, since it cannot - at least, in the contemporary world - be defined or measured. Virginity is still idealised in many communities because male hegemony persists; a belief in the importance of virginity is a measure of social control of women. Fortunately for many women, however, it has always been and still is possible to fake virginity, in the twenty-first century as in all previous ages.
\end{abstract}

Keywords: Feminism, virginity, enlightenment, cultural practices

\section{Introduction}

Virginity is a concept fogged and obscured by superstition, folklore, false science and the fear induced by repressive 'honour' societies. Its importance in most Western communities, which reached its peak at the zenith of the colonial era, waned significantly after that, probably reaching its nadir in the 1970s and 1980s. In Muslim societies, anxiety about female virginity may be at an all-time high now, as growing religious fundamentalism increasingly encounters and opposes Western values. Here in South Africa, the concept has been under the spotlight recently because of the revival of the Zulu custom of virginity testing, which has gained momentum in response to the HIV/AIDS pandemic. Since abstinence from certain sexual practices is among the most reliable ways of preventing HIV/AIDS, the concept of virginity has recently become more popular again even in Western societies, especially among Christian fundamentalist groups. But, despite all this attention and publicity, not to mention its cult status in certain places and times, virginity is a surprisingly difficult concept to define. Crudely equating female virginity with the presence of a hymen, for example, is simply inadequate. Defining the concept for either or both sexes as physical purity or sexual innocence may be a better start, but neither 'purity' nor 'innocence' is easy to pin down, especially in the context of a post-pubescent adult of reasonable intelligence and natural curiosity. And if we reject the mental or spiritual definition and go simply for behaviour, identifying virginity as abstention from sex, we discover the can of worms, opened dramatically by President Bill Clinton of the United States, that is the question of what exactly constitutes a sexual act. This paper aims to examine some of these issues under the relentless and perhaps embarrassing light of reason, asking among its critical questions whether virginity exists at all except as an instrument of social control - and, of course, how it can be faked by the ever-resourceful subverters of the social order.

I start by sampling some historical and cultural interpretations before I plunge into the ontological question, for this time and space, of what exactly virginity is. My investigation will mainly confine itself - supporting, alas, the traditional double standard - to the issue of female virginity.

\section{Classical and Oriental interpretations}

To the Ancient Greeks and Romans, a virgin was a young girl who had not yet reached puberty. This was a vulnerable and mysterious stage in a person's life because she was regarded as not yet fully female; she would become so only when she started menstruating and when she began having sexual relations with a man (Hanson 2007:4 I-47). Hence the young girl was seen as androgynous or even masculine, with a hard angular body like a man. She is often depicted, for example in statues of the virginal goddess Artemis, as boyish in figure and dress, and engaged in masculine pursuits such as hunting with a bow and arrow. Three of the most important Olympian goddesses, Artemis/Diana, Athena/Minerva and Hestia/ Vesta were virgins, and this fact contributed to their powers (Irwin 2007:15). Because they were liminal figures occupying a position between childhood and adulthood, between male and female, even human virgins were regarded as in some ways uncanny or sacred (MacLachlan 2007:7-8). The legendary Amazons derived some of their military prowess from their famed virginity. The safety of Rome was ensured by a cult of Vestal Virgins, whose closed bodies represented the closed and inviolate walls of the city (Parker 2007:69). This sense of mana associated with the pre-adolescent girl persists in the Hindu cult of Kumari, still practised in both India and Nepal (Allen 1975:3-4).

I. Catherine Addison, PhD, is an Associate Professor in the Department of English at the University of Zululand, South Africa. 


\section{Christian interpretations}

Early Christian interpretations also emphasise the sacred and magical qualities of virginity, seeing them in the greatest of the saints, Mary the mother of Jesus, and also in the lives of other female saints, martyrs and virtuous women (Cooper 2007: 106). Virgins were believed to be able to overpower would-be rapists, to cure certain ills and to capture unicorns. In the Christian view, virginity was not just a stage passed through by young girls, but a state in which a woman could remain for her whole life, and one which sanctified her and made her fitter for heaven than other, tainted mortals. The medieval Catholic Church was strongly influenced by St Paul who, though he gives guidelines for honourable marriage to both sexes in his First Epistle to the Corinthians, nevertheless betrays a preference for his own, celibate state. 'It is better to marry than to burn', he writes, prefacing this with the wistful remark: 'I would that all men were even as I myself' - in other words, unmarried and continent (I Corinthians 7-9). Following this precept in the Middle Ages, people tended to believe that sex was in itself sinful, polluting the Temple of the body. Even between a husband and wife, sex was officially discouraged during the woman's menstrual period, during her pregnancy, during Lent, Advent and Pentecost, and on all Wednesdays, Fridays and Saturdays (Blank 2007:152-153). It is not surprising that, by the twelfth century, all clergy had to be celibate, for spiritual purity was seen as exclusive of sexuality in all its forms.

This view of virginity was greatly tempered by the Reformation (Carpenter 2005:20). To the Protestant, abhorring all things Catholic, especially the nunneries and monasteries, virginity returned to its earlier status of a stage in the life of a woman, through which she would rapidly pass in order to achieve her true calling of wife and mother. Studying Paul's guidelines for the married and ignoring his personal preferences, the Reformed Churches advocated chastity of the married variety for both sexes. Though a young woman was of course expected to be a virgin at marriage, this was not a long-lived or especially important form of chastity (Blank 2007:18I).

\section{3 'Honour' societies - modern Islamic and others}

'Honour' societies are strongly patriarchal and patrilineal societies in which women's freedom is severely curtailed, mainly by their male relatives. Most of them nowadays are Islamic. In these societies, a family's 'honour', which is of enormous importance to its male members, is dependent on the legitimacy of its succession from one (male) generation to another, and so the sexuality of women is policed with draconian strictness throughout their fertile lives. According to Sharif Kanaana, in the early Middle Eastern context 'Women for the tribe were considered a factory for making men' (Ruggi 1998). The virginity of daughters was the property of the male members of her family, to be given as a gift to other men in order to cement ties with their families.

Although valuing women for their ability to reproduce legitimately is not unique to 'honour' societies - it probably underlies most customary gender arrangements in most societies - 'honour' societies police their women much more strictly and cruelly than others. In 'honour' societies, unmarried women who are suspected of not being virgins are in danger of their lives, and many are killed, tortured and/or mutilated by such punishments as having their faces burned with acids or slashed with razors. The perpetrators are usually the women's own male relatives - brothers, cousins, fathers - who feel that the woman's behaviour has damaged the 'honour' of the family. It makes no difference in some of these killings whether the woman has had sexual relations voluntarily or not: the victim of rape is as shameful as the willing lover. Many of these murders are perpetrated without the woman having had sex at all, but simply because she has become too 'Westernised'. The word 'Westernised' has become a catch-all phrase for non-Western conservatives the world over; it is used to describe any member of a non-Western society who attempts to claim any personal freedoms for herself or himself. In some cases the young woman killed for family 'honour' has simply refused to cover her head with a scarf, or travelled in a car with a man who was not related to her (Chesler 2009).

'Honour' societies have, of course, existed in many countries and periods and can operate in the name of almost any religion. Although at the moment most 'honour' killers are Muslims, at other times ancient Greek and Roman, Sikh, Hindu and Christian family members have been guilty of 'honour' killings of their own female relatives suspected of unsanctioned virginity loss. Even in South Africa, girls who have failed virginity tests have been ostracised and even severely assaulted for humiliating their families (Chesler 2009; Ruggi 1998; Blank, 2007 9, I23-124, 255).

\section{The West - nineteenth century}

In Western Europe and North America, anxiety about virginity probably reached a peak during Victorian times when virginity, at least for middle-class women, was non-negotiable at the time of marriage. Moreover, the young woman had to be totally ignorant of sexual matters. She would be assiduously protected in her upbringing from encountering any sexual material (Carpenter 2005:24): books, artworks, conversations and experiences would be rigorously censored. Popular legend has it that the edible parts of a chicken were linguistically adjusted to 'dark meat' and 'light meat' to avoid introducing the extremely titillating terms 'thigh' and 'breast'; and that even the legs of tables were covered up to deter 
lascivious thoughts. An unmarried woman would ideally have no knowledge whatsoever of the male anatomy and scarcely any of her own. The wedding night was intended to be a total and, one imagines, not usually very pleasant, surprise for the bride.

While this huge cover-up may have been successful in keeping some women temporarily ignorant of the facts of life, it is probably partially responsible for the great increase in demand for the services of prostitutes during the Victorian period. Brothels burgeoned in European cities at this time, perhaps suggesting that when large numbers of one gender are rigorously taught to look away in disgust from all anatomical and sensual matters, their sex lives after marriage are likely to be unenthusiastic at best, with shock and disgust very likely accompaniments. Queen Victoria is supposed to have advised one of her daughters before her wedding to 'lie back, close your eyes and think of England' and, even if this tale is apocryphal, gritting their teeth and hoping it would be over quickly was probably the experience of more wives then than now - sending many husbands into the arms of prostitutes for a warmer reception.

\section{The West - twentieth to twenty-first century}

Since the middle of the twentieth century - and especially since the widespread Youth rebellion of the 1960s, the value of virginity has radically decreased in nearly all Western societies - so much so that many young women in the 1970s and 1980s regarded virginity as a handicap and embarrassment that needed to be overcome as quickly as possible (Carpenter 2005:2). However, in the 1990s a conservative backlash against feminism and a gradual but widespread fear of AIDS triggered a change in attitude towards virginity, particularly in conservative and religious groups. It has become fashionable, especially in some American communities, for young people to pledge themselves to remain virgins until marriage. (Follow-up research shows, however, that the success rate of the pledge system is not impressively high [Blank 2007:247].)

\section{South Africa - twenty-first century}

Different cultural groups in South Africa have typically regarded female virginity in different ways. Most groups were influenced by the West's devaluation of virginity in the twentieth century, and, as in the West, there is at the present time a change afoot, noticeable for example in the recently reinstated custom of virginity testing in Zulu communities. As in the West, the increased value placed on virginity has coincided with the worldwide prevalence of HIV and AIDS, because of the known connection between some kinds of sex and HIV infection. Historically, in Zulu society, prospective brides were inspected by older women to ascertain their virginity. If a woman was proclaimed a virgin at the time of marriage, her bride-price was increased by one cow; so her virginity was a matter of economic importance to her father's family.

\section{So what is a virgin - really?}

Thus female virginity has been an important icon or commodity in many cultures in many times and places, intricately bound up with the value and even safety of individual women in those cultures. All this is interesting and informative, but it begs the crucial question: what, exactly, is a virgin?

Most people regard this question as more complex in the case of male virgins than female ones. However, as the investigation will go on to demonstrate, female virginity is probably just as difficult to pin down as male virginity. The reason for society's fixation on female virginity must remain the age-old masculine anxiety about fatherhood. Male members of most societies would like to pass something on to their own (preferably male) offspring - but how can they know their own offspring if these are conceived and incubated in female bodies? Although the separate, roving-eyed female body cannot finally be trusted, even with the most rigorous of sexual restraints, if this body is virgin at the outset there is a good chance that at least the firstborn child is legitimate. The issue of male virginity is not related as crucially to legitimacy and hence is not as interesting to most societies.

Thus, an obvious answer to the question 'What is a virgin?' is 'A woman who has never had sex'. But this answer is far from sufficient. If we are to seek any real enlightenment on our shadowy topic we need to probe, dilate and anatomise it carefully. The ancient Greeks and Romans, who regarded most women as inferior beings whose main function was reproductive, would have been satisfied with this simplistic definition. To them, a girl was a virgin mainly because she was not yet sexually mature. As soon as she was she would be married off to have her womanhood completed by a man who, in penetrating her, would encourage a bloodflow that was identified with menstrual blood, the sign of female adulthood (Hanson 2007:49). Penetration would, according to the medical theory of the times, open a girl's closed passages and her too-dense, manlike flesh, causing her body to acquire the soft sponginess regarded as characteristic of women (Hanson 2007:42). Similar views of virginity are not uncommon in South Africa, where some virginity testers claim that they can identify virgins from the way they walk and the consistency of their flesh (Mthalane 2000:24).

The early Christians would have answered the question differently, as virginity and in particular the virginity of the Virgin Mary, was not a physical but a spiritual state (Carpenter 2005:19), a state of absolute sexual purity, disturbed by no Inkanyiso, Jnl Hum \& Soc Sci 2010, 2(2) 
carnal desires or sensual thoughts whatsoever. Since sex was regarded as in and of itself sinful, the highest form of virtue was naturally repellent to all aspects and suggestions of sexuality. This ideal of virginity is epitomised in the beautiful medieval poem 'I Sing of a Maiden', which meditates on the absolute stillness and passionlessness of the moment of Jesus' conception. In the almost indiscernible formation of dew on flower and leaf the poet finds a parallel to Mary's divine impregnation, and discovers in it proof of her perfect virtue:

\author{
I sing of a maiden \\ That is makeles: \\ King of alle kinges \\ To here sone she ches. \\ He cam also stille \\ Ther his moder was, \\ As dew in Aprille \\ That falleth on the grass. \\ He cam also stille \\ To his moderes bowr, \\ As dew in Aprille \\ That falleth on the flowr. \\ He cam also stille \\ Ther his moder lay, \\ As dewe in Aprille \\ That falleth on the spray. \\ Moder and maiden \\ Was nevere noon but she: \\ Wel may swich a lady \\ Godes moder be (Davies 1963:155).
}

Just as St Mary preserved her virginity all her life (in spite of childbirth!), saintly women in medieval times strove to remain permanent virgins, for this not only freed them from subjection to a husband and the dangers of childbirth, but gave them access to a higher form of chastity than the married state and allowed them to aspire to the continent virtue preferred by St Paul.

After the Reformation, the idea of the virgin's mystical autonomy died down and virginity became once again a mere commodity bought and sold on the marriage market. In order to assure the quality of the goods exchanged, the virgin needed a trade mark or identifying sign more reliable than reputation or verbal guarantee. This they found in the presence of the intact hymen. Though both Greeks and early Christians were interested in the bleeding associated with a virgin's defloration, neither society recognised the existence of the hymen. In the West, the hymen was discovered only in the fifteenth century by an Italian doctor called Michael Savonarola, though a variety of earlier writings did suggest the existence of some 'obstruction' of the vagina that would cause bleeding at first penetration (Blank 2007:45, 46-49). But, once discovered and established in medical and legal writings, the hymen became the triumphant empirical answer to the question 'What is virginity?' While young women in the Victorian period were required to remain as oblivious of sexual matters as the Blessed Virgin herself, the actual proof of their virtue lay not in abstract qualities such as innocence and purity but in the physical existence of a small and somewhat vaguely described membrane between their legs.

This membrane's objective, reliable existence has proved crucial to the concept of virginity in the modern era, when ideas of 'innocence' and 'purity' have become vaguer and less positive. In the contemporary world, it is no longer possible to distinguish innocence from plain ignorance. And, even if ignorance were desirable, it cannot be achieved in an information age except by control and censorship not only of pornography but of important knowledge. Once someone knows the facts of human reproduction, surely she is already not innocent?

For we cannot, as the Greeks did, simply focus on action instead of mental state and define a virgin as someone who has not participated in sexual acts. This is because the concept of a sexual act is a minefield - the minefield trodden a few years ago by Bill Clinton when he claimed, after being caught in flagrante, that he 'did not have sex with that woman'. But 
even for someone devoid of Clinton's sophisms about oral sex, the definition of a sex act is immensely difficult. Sigmund Freud (1920) claimed that the human infant is a 'polymorphic pervert', able to experience sexuality via every element of its body and mind. We remain as adults versatile and complex sexual beings. Just imagining a sex act is a kind of participation; once personal inquiry leads to discovery of the young individual's own body parts - with their own hypersensitivity to touch - what then? It is almost impossible to imagine sexual innocence in an adult of normal intelligence and curiosity. Is masturbation loss of virginity? Perhaps, especially for those with vivid and varied imaginations.

But we could ignore auto-eroticism and turn to erotic relationships. For a couple in love, the question is how far they can go without losing their virginity. Can they hold hands? Can they kiss? Some contemporary Muslims would say 'no' to both these questions, though the Victorians would have given them an uneasy 'yes', as long as the parties were betrothed. In the West in the 1950s the answers would have been 'yes' in both cases, and even more freedoms were generally countenanced under the new term, 'necking'. In fact, a woman might in this period remain a 'technical virgin' even if she indulged in another newly-defined activity, 'heavy petting' - which might well bring one or both lovers to orgasm (Carpenter 2005:34).

But here we have got very far away from any ideas of innocence or abstention and come right back to the mere physical existence of a hymen. 'Heavy petting' is just a nonce term for various kinds of non-penetrative sex. As with oral sex for Bill Clinton, non-penetrative sex is usually excluded from the definition of a sex act because of the reigning ideology of patriarchy and heterosexuality. 'Sex' is an act of ownership and impregnation - and an act that must mark a woman like a cattle brand as the property of one man - one man who does not want to share or deal in second-hand goods. It has nothing to do with erotic experience or preference. Despite the fact that a great many women - and some men, both gay and straight - derive greater pleasure from non-penetrative sex than penetrative sex, despite the fact that some men, both gay and straight, prefer anal to vaginal penetration, 'sex' must, by most people's definition, necessitate the penetration of a vagina by a penis - the basic reproductive act. Because of this hegemonic definition, and the fact that some women possess hymens which may be broken and bleed during their first encounter with this kind of sex, a woman is generally regarded as a virgin if she possesses a hymen. It is a short step to the conclusion that a woman is a virgin only if she possesses a hymen.

And yet, pace all the men who place their hopes of legitimate offspring on the existence of hymens, these elusive membranes are not reliable markers of the quality that they cherish. (Which is not sexual innocence by any means; many sexually active lesbians, for example, remain virgins all their lives by the hymen definition.) Recently, because of the growth of forensic medicine and the prevalence of child abuse, a great deal of research has been done on the hymen, and it has been found to be a confusing indicator. Firstly, hymens are so different in appearance, shape, colour and texture as to make it difficult to generalise about them at all. Secondly, in the girl child and young woman, a hymen can change shape and nature quite radically from year to year on its own. Some are so fragile as to disappear more or less spontaneously or because of exercise, tampons or minor manipulations; others are very thick and robust and even sometimes imperforate; a few are extremely resilient and survive years of intercourse to be removed at the time of childbirth; rare ones actually grow back after removal - in a recorded case history, more than once. A hymenal tear is never on its own evidence of sexual penetration (Blank 2007:35-4I).

Thus, even this last hope, this empirical physical marker that has nothing to do with spiritual or moral qualities, the hymen, has proved to be an unreliable indicator, a defective and deceitful sign, giving both false positives and false negatives for a quality which tends to disappear - at least from the contemporary world - as soon as it is scrutinised closely and clearly.

\section{8}

\subsection{Virginity testing}

All this throws an interesting light on the virginity testing being conducted all over the province of KwaZulu-Natal. As numerous surveys have pointed out, the tests pose an injustice - a threat of ostracism or reprimand to all the women found not to possess a hymen and also an infringement of one of the rights entrenched in our Constitution: the right to bodily integrity (Le Roux 2006:I5-I8; P Dlamini 2000:27; C Dlamini 2000:37; Mabusela 2000:29; South Africa 1996:8). This is the case whether the woman in question seems to lack a hymen because she was born like that, has lost it exercising, was abused or raped or even if she actually engaged in consensual sex and got some pleasure out of it. This is the case also if the woman possesses an unusual hymen, not recognised as such by the testers. This is the case whether the test is performed in public so that the humiliation is felt even by those declared intact, or whether it is performed in private, with its results kept confidential; whether the subject is a child too young to decide for herself or a woman over sixteen who has signed a consent form (as is at present legislated by the new Children's Act [South Africa 2005:36]). The whole system will not stand up to the unblinking scrutiny of reason. A woman who has spent years in a lesbian Inkanyiso, Jnl Hum \& Soc Sci 2010, 2(2) 
relationship may 'pass' the test, as may a woman who has contracted HIV from a partner who favours anal sex - a practice that some researchers claim is growing in response to the virginity testing trend, and which is more likely to infect the 'passive' partner with HIV than other sexual acts (George 2007:16).

\subsection{Faking it}

On a lighter note, virginity tests may fail to record 'accurate' results for other reasons. Just as women have probably always faked orgasm, so have they faked virginity - in this case the existence of the hymen. Even in the ancient world, some doctors and midwives would help brides with herbal astringents, irritants and drying and tightening agents, as well as with sponges or soft capsules filled with blood in order to trick bridegrooms into believing that a defloration had occurred (Hanson 2007:56-57; Blank 2007:86-87). South African researchers record young women using toothpaste and pieces of meat to fool local virginity testers (Le Roux 2006:15); none yet seems to have taken cognizance of the fact that one can purchase a fake hymen - complete with synthetic blood - at a sex shop (Olien 2010) or undergo the simple surgery called hymenorraphy (hymen repair) or the slightly less simple hymenoplasty (hymen reconstruction) (Blank 2007:72). Dr Fayman of Rosebank, Johannesburg, has the following advertisement posted on the Internet under the heading 'Hymen Repair':

This cosmetic surgery procedure is designed to restore the structure of the perforated hymen. The operation enjoys popularity in certain cultural and religious contexts. Plastic Surgery length is 30 to 45 minutes. Conscious sedation with local anaesthesia is preferred. The procedure is done on a day-basis and no hospitalisation is required. Recovery is usually prompt and painless. Sexual activity is discouraged for four to six weeks (http://www.doctorfayman.co.za/other_hymen.html).

\section{Conclusion}

I must conclude that virginity is a quality that tends to disappear under the clear and unrelenting eye of reason. In the contemporary world innocence is neither possible nor desirable for the young adult; the hymen, like all other physiological markers of virginity, is unreliable even as a sign of one particular type of sex act; and human sexuality is so various and multifacetted that to pin it down to any particular kind of activity is grossly inadequate. Female virginity becomes an icon or a cult only in the presence of masculine oppression or hegemony; it is a measure of social control whose origin is masculine unease about legitimacy.

\section{References}

Allen, Michael R. 1975. The Cult of Kumari. Kathmandu: Madhab Lal Maharjan.

Blank, Hanne. 2007. Virgin: The Untouched History. New York: Bloomsbury.

Carpenter, Laura M. 2005. Virginity Lost: An Intimate Portrait of First Sexual Experiences. New York: New York University Press.

Chesler, Phyllis. 2009. Are Honor Killings Simply Domestic Violence? Middle East Quarterly 16.2. Accessed online at: http:// www.meforum.org/2067/are-honor-killings-simply-domestic-violence, on September 19, 2010.

Cooper, Kate. 2007. 'Only Virgins Can Give Birth to Christ': The Virgin Mary and the Problem of Female Authority in Late Antiquity. In MacLachlan \& Fletcher. 100-II5.

Davies, R. T. (ed). 1963. Medieval English Lyrics: A Critical Anthology. London: Faber \& Faber.

Dlamini, Charles. 2000. The Constitution and the Practice of Cultures. Proceedings of the Consultative Conference on Virginity Testing. Richards Bay, June I2-14, 2000. 34-37.

Dlamini, Phiwase. 2000. Sociological Perspective on Virginity Testing. Proceedings of the Consultative Conference on Virginity Testing. Richards Bay, June I2-I4, 2000. 27-28.

Freud, Sigmund. 1920. Three Contributions to the Theory of Sex. $2^{\text {nd }}$ Edition. Transl. A A Brill. New York: Nervous and Mental Disease Publishing Co. Accessed at: http://www.gutenberg.org/cache/epub//4969/pg/4969.txt, on October 8, 2010.

George, Erika R. 2007. Like a Virgin? Virginity Testing as HIV/AIDS Prevention: Human Rights Universalism and Cultural Relativism Revisited. Accessed at:

http://digitalcommons. law.umaryland.edu/cgi/viewcontent.cgi?article =1003\&context =iclc_papers, on October 7, 2010.

Hanson, Ann Ellis. 2007. The Hippocratic Parthenos in Sickness and Health. In MacLachlan \& Fletcher. 40-65.

Hymen Repair. ND. Accessed online at: http://www.doctorfayman.co.za/other_hymen.html, on October 7, 2010.

Irwin, Eleanor. 2007. The Invention of Virginity on Olympus. In MacLachlan \& Fletcher. 13-23.

Le Roux, Lucinda. 2006. Harmful Traditonal Practices (Male Circumcision and Virginity Testing of Girls) and the Legal Rights of Children. Cape Town. University of the Western Cape. LIM-Thesis.

Mabusela, Shirley. 2000. Children's Rights. Proceedings of the Consultative Conference on Virginity Testing. Richards Bay, June I2-I4, 2000. 28-30.

MacLachlan, Bonnie. 2007. Introduction. In MacLachlan \& Fletcher. 3-I2.

MacLachlan, Bonnie, and Fletcher, Judith (eds). 2007. Virginity Revisited: Configurations of the Unpossessed Body. Toronto: University of Toronto Press.

Mthalane, Lisa. 2000. Virginity Testing. Proceedings of the Consultative Conference on Virginity Testing. Richards Bay, June I2I4, 2000. 24-26. 
Olien, Jessica. 2010. Virginity for Sale. Marie Claire, January 20. Accessed online at: http://www.marieclaire.com/world-reports/ opinion/fake-hymens-for-sale, on October 7, 2010.

Parker, Holt N. 2007. Why Were the Vestals Virgins? Or the Chastity of Women and the Safety of the Roman State. In MacLachlan \& Fletcher. 66-99.

Ruggi, Suzanne. 1998. Commodifying Honor in Female Sexuality: Honor Killings in Palestine. Middle East Report 206. Accessed online at: http://www.merip.org/mer/mer206/ruggi.htm, on September 19, 2010.

South Africa. 1996. The Constitution of the Republic of South Africa, Act 108 of 1996. Pretoria: Government Printer.

South Africa. 2005. Children's Act, No 38 of 2005. Pretoria: Government Printer. [Laws.] Accessed online at: http:// www.info.gov.za/view/DownloadFileAction?id=67892 on October 7, 2010. 